\section{SAY NO.}

DY D. C. COLegworthy.

When tempted to wander from duty and truth, youth,-

Have courage to answer the soft smiling foe,

And when you are tempted' say earnestly, no

When the glass that is sparkling is pressed to the lip,

Andcheerfulcompanionsinvite you to sip, Beware of the serpent beneath the rich glow, And dash the bright wine cup, with a hearty no, no :

The gamester may teach you, with his deep burning wiles,

With words that are pleasant and face full of smiles,

In sport he may ask you the dice-box to throw, Be firm in your virtue-Indignant say, no !

The way that is infamous, which multitudes throng:

With music and dancing and soul-melting song Tis Beauty that beckons and asks you to go ; A way from false splendor,-say heartily, no!

With looks that are smiling and words that are fair,

Wherever the tempter may meet you, beware ? Like an angel of mercy all sweetness and bloom
Enticing the thoughtless, the syren may come.

0 , ponder your footsteps, leap notin the dark; Upon the wild ocean launch not your frail bark Without the true wisdom that God will bestow

When beckoned by error. say earnestly, no !

Take, take the good Bible for your guide and your chart,

And bind its pure precepts close, close to thy

$\mathbf{O}$, then with the profligate you never will go,

But ever when tempted, say heartily NO !

\section{Taylor on the Batsio Flesd}

Lieut. Corwin, writing an account of the

battle, says of Gen. Taylor. "He took his po-

sition on a commanding height overlooking the

two armies. The enemy, who had succeeded

in gaining an advantageous position, made

fierce charge upon our column, and fought with a desperation that seemed for a time to insur success to their arms. And when he saw the enemy give way and setreat in the utmost confusion, he gave free vent to his pent up feelings. His right leg was q̊nickly disengage in the whole of the fierce encounter-his arms, which were calmly tolded ove ter-his arms, which were calmly tolded over
his breast, relaxed their hold-his feet fairly his breast, relaxed their hold-his feet fairly danced in the stirrups, and his whole body was in motion. It was a moment of the most exciting and intense inteiest. His face was suffused with tears. The day was won-the victory complete-his little army saved from the disgrace of a defeat, and he could not refrain from weeping for jov at what seemed to so ma ny, buta moment bef ore, as an impossible result. A Village ror Sale.

To show the effects of the great emigration to America, the entire village of Meimbresso in the Electorate of Cassel, is offered for sale, 2s all the inhabitants, 600 , are about to leave for the United States

Captured Cannon.

We have captured from Mexico since the commencement of the war, 8 pieces of cannon at Resaca, 20 at Matamoras, 50 at Monterey, 400 at Vera Cruz, 50 at Alvarado, and 8 at Cerro Gordo ; at Tuspan (probably) 20about 560 pieces.

\section{Interesting Colncldence}

Three male infants were baptised in a Pres byterian church at Rochester last week. Their mothers were sisters, the efficiating minister was their brother and there were twenty of the same family present on the occasion.

A Fool's Heart is in his Pen.

The man who stole $\$ 84$ from Miss Fairfield and afterwards promised by letter to return it with interest, when he got ready, has been discovered and arrested, through the handwriting of his epistle.

\section{A Strange Animal.}

According to Louisville papers, a wonder ful animal has been caught at the Rocky Mountains, about the size of a horee, and covered with short fine wool. It is a regular one ever seeve.
LoUdon, N. H., APRIJ, 3, 1847. Mr. Editor:-

$I$ beg leave to address you as an old acquain tance, feeling as such, having 1 ead your paper, the "Scientific American," sfnce vol. 1, No. 49 , with much pleasure and satisfaction, dill add, with great interest. I notice that you give correspondents every indulgence,
and all the information they ask respecting new inventions, I therefore make bold to ask your opinion concerning power gained by the buryancy of water, with a machine which will describe thus :

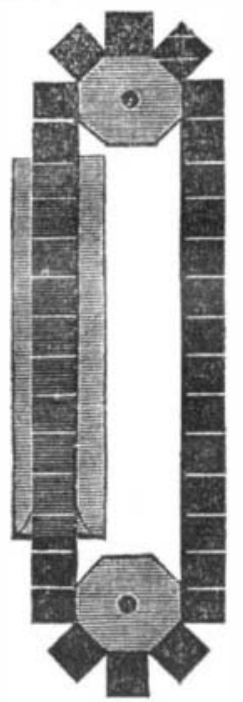

Suppose two shafts to be hung horizontally ne as low as circumstances will admit; the other some 20 feet directly over it, more or less, having on each a drum made eight one foot ; then add a band made of boxes on foot square every way, and connect them together by means of stout hinges, a sufficien number to reach around both of these drums then place a cistern so that one part of thi band of boxes will pass through it. Let this cistern stand upright, and have it as tall as it will stand between the two drums, with a hole in the bottom barely sufficient to let this train we will place some flaps of leather around this hole and nail them to the bottom of the istern, and let them lay up against the boxes as they pass upward ; these flaps are to limi the escape of water at the bottom when the
cistern is full. Now these boxes being air cistern is full. Now these boxes being air tight, will not the water raise them and set the drums in motion?

Yours, \&c.

Yours, \&c. HENRY H. AYER. which you will have to encounter, - which you have overlooked and which spoils the invention,-is the resistance of water against the boxes while they are passing up into the cistern. Whatever may be the height of the cistern or the depth of the water, the resistbe just equal to the entire force of bunyancy during the ascent of the box through the water. To be more explicit, the entire column of water is necessarily eievated a certain dis tance by the entrance of each box : what constivutes the buoyancy of the hox, is the gravity of the water which is accommorated in the descent of the water in proportion to the elevation of the box; and when the box has
reached the surface, the same quantity of water will have thereby descended the same dis. ance which it was raised by the box in the first instance.- $\mathrm{ED}_{\mathrm{D}}$

\section{A Traltor.}

It is said that an American who was well known in Santa $\mathrm{Fe}$, fought hard against the Americans, and with his very good rifle killed most of those who fell dead. When the fortress was taken, he endeavored to make his escape, but fell with thirty odd balls through on him simultaneously.

In 1800 , a year of great scarcity an act was passed prohibiting bakers from offering their bread for sale untıl twenty-four hours after it was baked.

The Star Spangled Banner, of Boston, recenty published

THE WEATHER, \&C.

WEDNESDay, May 5 th. Hours, P. M.
Hours, A. M.

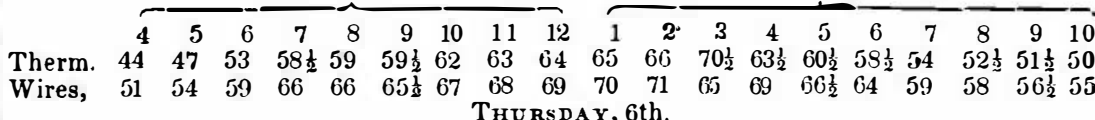

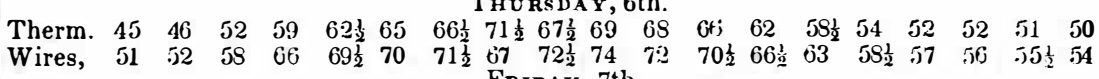

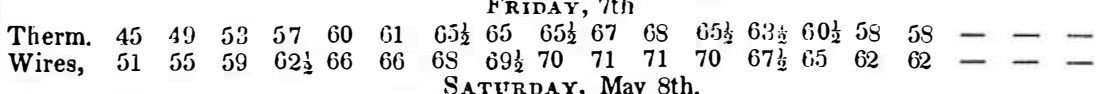

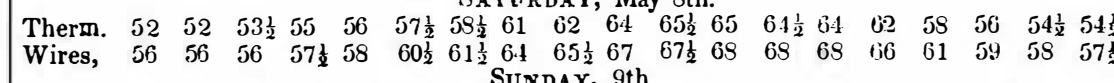

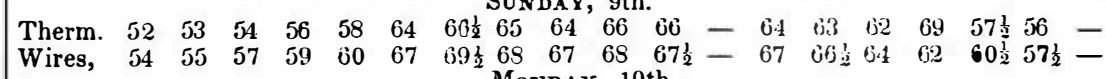

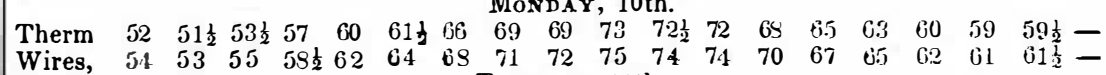
Wires, 54 53 55 $58 \frac{1}{2} 62$ TuEsDAY. 11 th.

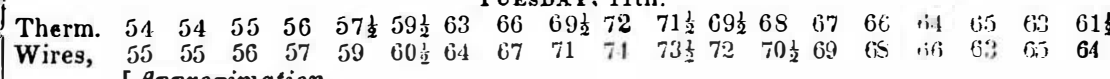
[Approximation.

REMARKS.
The wires have been but partially eouilibriated during the week ending with Tuesday, May 12, but the wires and thermometer have been gradually approximating and this morning, at 5 o'clock, marked the temperature with a variance of but one degree Yesterday morning the variance was two degrees-both mornings had a clouded atmosphere with much fog. The large black bugs made their appearfog. The large black bugs made their appear-
ance yesterday morning in great numbers, and again this morning. Fain fell at 2 P. M. Saturday, May 8 . Thursday, May 6 , the smoke hanging over the city became a cloud and was f a redish hue. Monday, May 3, I noted an equilibration in my last week's memorandum of long duration. In the Brooklyn Star of that

\section{Wealth of the RiverAmazon, South} America.

We some time since noticed the fact, that celebrated English nautical and mining engineer had been exploring the country up the Amazon and made some valuable discoveries as to the existence of extensive deposits of the precious metals, auriferious san $l$ in the streams, and many botanical specimens çuite unknown in this country. A company was formed in the United States to endeavor to reap the advantages of these discoveries; and the Irench sent out an expedition two or three unsuccessful, as another is now forming to $g$. out in the Astrolabe corvette and Alecton steamer, of eighty hotse power. The Academy of Science, under the direction of M. Ara go, have given all the necessary instruction to the officers; and these vessels will leave,early in the spring, for the Brazils From the discoveries which have been made it is presumAmazon and the Pacific, or, at least, a very slight interruption. The result is looked forward to with greatinterest by scientific men, as there appears to be no doubt entertained of the existence of large quantities of mineral wealth. The Anglo-American Company are already prosecuting their researches, and have several narrow boats, drawing but little water, some of which are worked by steam, far up
the river. From these exertions it is not to much to expect that $n$ e shall soon be in posmuch to expect that ne shall soon be in pos-
session of some most interesting information of the mineral and other natural resources, the inhabitants, zoology, botany, \&c., of this interesting but little known portion of the globe.

\section{cotton.}

Georgia Sea Island cotton is of a dull butte tint, the filament beingsome three times longer than that of the India cotton wool. The ease with which they are spun into cotton read.

Georgia Upland cotton is good for coarse It was called for a is short, light and feeble. from the fact that it was separated from the seed by the blows of a bow-string.

Tennessee cotton is of nearly the same quality as the Georgia Upland, except that it is ceaner and the staple a little longer.

New Orleans cotton is superior to the last two named kinds, and may be said to occupy a middle point between Sea Island and Georgia Upland.

day I noted the state of the wires of that day and of the two previous days and that a two fold disturbance was indicated. Accounts have since reached us of a snow storm at Bangor Maine, on the 3d, and snow in Otsego Count on the $2 \mathrm{~d}$, and rains South on the first and second. When time elapses for further accounts, I have no doubt that we shall have accounts of a lightnıng storm on Saturday or Sunday, which originated in a terrestrial dis turbance. A correspondent writes me from the banks of the Au Sable, May 5, that the snow was quite deep in the woods in that vicinity, the Au Sable heads among the Adiron dack Mountains west of Lake Champlain.

Brooklyn Heights, May 11, 1847 . E. MERIAM

clean and uniform, and yarns made from it are in great request among the stocking weavers Demerara, Berenice and Maranham cottons re fine and glossy, and well cleaned. They re spun into a fair stout yarn.

Bahia cotton is better than either of the swo inds last named.

Surinam cotton has a long staple, and is faintly tinged with yellow. It is clean, and much sought after by hoosier

West India cotton is trom Bourbon seedthe staple is fine and silks, hut not well pre. pared.

Barbadoescottu!! has a silort staple, but is silky and strons. It appears in the market with much husk.

\title{
More Files.
}

The Dumfries Herald says, that on Monday forenoon, about ten o'clock, a shower of flies, which darkened the air as they descended, fell on the Annan road, about half a mile to the east of Dumfries, and cuvered the road for 600 or $700 \mathrm{yards}$, and the road was black with the crawling fies. 